\title{
PENERAPAN KNOWLEDGE MANAGEMENT DI SMK DIPONEGORO DEPOK
}

\author{
Yoga Anjas Pratama \\ Program Magister Manajemen dan Kebijakan Pendidikan Islam \\ Fakultas Ilmu Tarbiyah dan Keguruan UIN Sunan Kalijaga Yogyakarta \\ yogaanjas2@gmail.com
}

\begin{abstract}
Abstrak
Artikel ini membahas tentang konsep knowledge management dan penerapannya di SMK Diponegoro Depok. Konsep knowledge management ialah merupakan konsep pengelolaan terhadap sumber daya dan tekhnologi informasi yang dimiliki. Konsep ini berangkat dari dua teori yakni teori berbasis sumber daya (resource based theory) dan teori berbasis pengetahuan (knowledge based theory). Dalam lembaga pendidikan knowledge management diterapkan dalam bentuk peningkatan dan pemanfaatan sumber daya dan tekhnologi komunikasi dan informasi sebagai aset pengetahuan dalam meningkatkan keunggulan kompetitif. Knowledge management di SMK Diponegoro Depok diterapkan dalam bentuk peningkatan dan pemanfaatan pengetahuan pendidik, media teknologi komunikasi dan informasi, dan sharing-sharing pengetahuan. Dari mini research yang dilakukan di SMK Diponegoro Depok, ditemukan hal-hal sebagai berikut: (1) Telah dilakukanya peningkatan dan pemanfaatan sumber daya (2) Adanya penerapan sharing knowledge (3) Dilakukanya terbosan dalam peningkatan kualitas pendidik dan peserta didik (4) SMK Diponegoro mampu melihat peluang besar dari budaya penyebaran informasi (5) Kurang signifikanya penggunaan media tekhnologi komunikasi dan informasi di SMK Diponegoro Depok.
\end{abstract}

Kata Kunci: Knowledge Management, SMK Diponegoro Depok 


\section{PENDAHULUAN}

Perkembangan ilmu pengetahuan dan teknologi saat ini berjalan dengan begitu cepat. Kemampuan dari suatu lembaga pendidikan atau instutusi terhadap ilmu pengetahuan dan teknologi menjadi faktor yang sangat penting dalam kemajuan dan keberkembanganya. Ketika suatu lembaga pendidikan menginginkan peningkatan pada taraf kualitasnya, maka yang dibutuhkan adalah peningkatan pengetahuan pada setiap sumber daya manusia, sehingga lembaga pendidikan tersebut mampu bersaing, bertahan dan menunjukkan eksitensinya.

Knowledge management sebagai suatu konsep ialah merupakan suatu strategi yang mengubah aset intelektual organisasi, baik informasi yang sudah terekam maupun bakat dari anggotanya ke dalam produktivitas yang lebih tinggi, nilai-nilai baru, dan peningkatan daya saing.1 Konsep knowldege management ini meliputi pengelolaan sumber daya manusia, dan tekhnologi informasi, dalam rangka mencapai peningkatan kualitas.

Pada saat ini telah banyak organisasi atau perusahaan yang mengadopsi konsep knowledge management. Hal ini dikarenakan kuatnya persaingan global pada tiap organisasi atau perusahaan yang membutuhkan knowldege management dalam peningkatan kualitasnya. Selain pada organisasi dan perusahaan, saat ini knowldege managament telah di pakai di lembaga pendidikan namun kondisinya belum cukup banyak. Hal ini dikarenakan untuk menerapkan konsepsi knowldege management di lembaga pendidikan membutuhkan beberapa syarat, sebagai berikut:

Pertama, pemimpin harus dapat menyiapkan sumber daya yang terlatih untuk menunjang knowledge management, serta dapat memberikan perhatian yang lebih pada proses menciptakan, mentransfer, membagi pengetahuan dalam organisasi dan menghargai pengalaman yang dimiliki oleh staf. Kedua, Dibutuhkan iklim organisasi yang kondusif, kepemimpinan yang mendukung, ketersediaan sumber daya manusia dan prasarana pendukung yang sangat berperan dalam efektivitas knowledge management. 2

Knowledge management pada umumnya sangat ideal untuk diterapkan pada lembaga pendidikan. Namun mengingat belum cukup banyaknya lembaga pendidikan yang menerapkan knowledge management, dan belum mengetahui manfaat dari knowldege management, serta dalam penerapanya membutuhkan kerjasama, manajemen yang baik dan peningkatan kualitas pada segi sumber daya manusia, dan tekhnologi informasi. Maka dalam hal ini penulis tertarik untuk mengulas knowledge management di lebaga pendidikan, yaitu: SMK Diponegoro Depok.

1Sangkala, Knowledge Management, (Jakarta: PT Grafindo Persada, 2007), hlm.27.

2Elsina Ferdinandus, et. al. "Model Knowledge Management dalam Organisasi

Pendidikan” Jurnal Pendidikan Humaniora, Vol. 3. No. 2. 107. 


\section{Konsep Knowledge Management}

Knowledge management merupakan manajemen informasi di sebuah organisasi dengan menjalankan strategi, struktur, budaya, sistem, dan kapasitas serta sikap individu-individu di organisasi tersebut terkait dengan pengetahuan yang dimilikinya.3

Santosu dan Surmarch sebagaimana yang dikutip Sangkala, memberi definisi bahwa knowledge management merupakan proses dimana perusahaan melahirkan nilai-nilai intellectual assets dan aset yang berbasiskan pengetahuan. 4

Knowledge management mempunyai beragam definisi yang berbedabeda jika dilihat dari subjek yang menggunakanya, baik itu perusahaan maupun organisasi-organisasi tertentu. Namun jika dilihat dari segi ilmu pengetahuan, teknologi, dan pendidikan maka knowledge management dapat di definisikan sebagai berikut:

Knowledge managament sebagai ilmu pengetahuan ialah merupakan pengetahuan-pandangan, pemahaman dan praktik mengetahui bagaimana (know-how) yang kita miliki adalah sumber daya dasar yang memungkinkan kita untuk menggunakanya dengan cerdas. Pengetahuan juga dapat dipindahkan kedalam bentuk lain seperti, buku, tekhnologi, praktis, dan tradisi disemua jenis dan organisasi dan masyarakat secara umum. Proses perpindahan ini menghasilkan pengalaman yang terakumulasi yang akan meningkatkan efektivitas jika digunakan secara tepat. Pengetahuan merupakan salah sat faktor utama yang menyebabkan seseorang atau individu, organisasi dan masyarakat dapat berprilaku cerdas.5

Knowledge management sebagai tekhnologi ialah merupakan konsep yang menitikberatkan pada keberadaan informasi yang diubah menjadi pengetahuan yang dapat diaplikasikan dan tersedia dalam berbagai bentuk yang dapat digunakan oleh siapapun. 6

Knowledge management sebagai pendidikan ialah merupakan kombinasi antara proses dan aplikasi sarana tekhnologi untuk mengelola, menyimpan, dan menyediakan secara universal melalui jaringan elektronik, akan proses penciptaan dan penyebaran pengetahuan mengenai kebijakan dan pengalaman pendidikan.7

3Nurul Indarti, en Dhiani Dyahjatmayanti, Manajemen Pengetahuan: Teori dan

Praktik, (Yogyakarta: Gadjah Mada University Press, 2015), hlm. 20

4Bambang Setiarso, et. al. Penerapan Knowledge Management Pada Organisasi, (Yogyakarta: Graha Ilmu, 2012), hlm 7.

5Nurul Indarti, en Dhiani Dyahjatmayanti, Manajemen Pengetahuan: Teori, ..., hlm. 21.

6Ibid.,

7Abdul Amin, "Knowledge Management: Konsep dan Aplikasinya di Perpustakaan", Jurnal Al-Maktabah, Vol. 2, No. 2, 73. 
Berdasarakan beberapa definisi diatas maka knowledge management dapat kita pahami sebagai suatu strategi dan proses pengelolaan terhadap ilmu pengetahuan, sumber daya manusia, dan informasi yang telah dimiliki kearah peningkatan kualitas sehingga mampu menambah aset pengetahuan dan meningkatkan keunggulan kompetitif.

Konsep knowledge management dapat dilihat dari dua teori: Pertama, teori berbasis sumber daya (resource based theory) ialah teori yang dikembangkan untuk memahami mengapa perusahaan berbeda-beda dan bagaimana perusahaan menggunakan sumber daya produktif yang dimilikinya dalam kegiatan operasionalnya. 8 Artinya semua sumber daya perusahaan yang terdiri dari semua aset, kapabilitas, proses organisasi, atribut perusahaan, informasi, pengetahuan, dan lain-lain, dapat digunakan sebaik mungkin sehingga memungkinkanya untuk memahami dan menerapkan strategi yang dapat meningkatkan efesiensi dan efektivitas perusahaan.

Kedua, teori berbasis pengetahuan (knowledge based theory) ialah teori yang didasarkan pada teori berbasis sumber daya. Teori ini memandang organisasi sebagai entititas pencipta pengetahuan (knowledge creating entities). Menurut teori ini pengetahuan dianggap sebagai sumber daya organisasi strategis yang paling signifikan.9

Menurut Toumi sebagaimana yang dikutip oleh Sangkala bahwasanya secara konseptual knowledge management dapat didekati dari empat arah, yaitu: Pertama, pemrosesan informasi perusahaan (organanizaitonal informasi processing). Kedua, intelijen bisnis (busniness intelligence). Ketiga, Kognisi perusahaan (organizational cognition). Keempat, pengembangan perusahaan (organizational Deploment). 10

\section{Penerapan Knowledge Management}

Knowledge merupakan hasil proses melalui interaksi sosial dengan orang lain dan lingkungan untuk menjadi tujuan kebenaran. Knowledge memiliki peran penting untuk mendukung budaya organisasi dan pemanfaatan teknologi informasi dalam melakukan knowledge transfer sebagai bagian intergral dari knowledge sharing. 11

Knowledge management atau manajemen pengetahuan dalam proses penerapanya tentu tidak terlepas dari pernanan sumber daya manusia dan tekhnologi. Hal ini dikarenakan sumber daya manusia dan teknologi merupakan bagian dari konsep knowledge management yang diyakini hlm. 24.

8 Nurul Indarti, en Dhiani Dyahjatmayanti, Manajemen Pengetahuan: Teori,...,

9 Ibid, hlm. 26.

10 Sangkala, Knowledge Management, ..., hlm.12.

11 Omar Dani Sopandi, "Implementasi Knowledge Management Pada Perguruan Tinggi”, Jurnal Admistrasi Pendidikan, Vol. XXII. No.2. 3. 
merupakan unsur utama dari keberhasilan penerapan knowledge management itu sendiri.12

Sumber daya manusia merupakan manusia yang bekerja dilingkungan suatu organisasi disebut juga personil, tenaga kerja, pegawai atau karyawan.13 Dengan begitu maka sumber daya manusia dalam konteks knowledge management dapat dikatakan sebagai sekumpulan anggota yang bekerja, orang atau people yang dapat dipemberdayakan sehingga dapat terbentuknya sharing dan manage knowledge.

Sharing dan manage knowledge yang dilakukan bertujuan untuk mendapatkan informasi dan pengetahuan. Informasi adalah data yang dilengkapi dengan relavansi dan tujuan. Kemudian informasi tersebut menjadi pengetahuan, ketika informasi telah mendapat tempat dalam kerangka acuan pengguna sehingga pengguna tersebut menghubungkan tindakanya dengan kerangka acuan tersebut.14 Dengan adanya informasi dan pengetahuan maka akan dapat meningkatkan produktivitas organisasi di berbagai bidang sehingga mampu membuat organisasi tersebut untuk bersaing dengan organisasi lainya.

Knowledge management dalam penerapanya terdiri dari tiga komponen yaitu people, place, dan content.15 Knowledge management dalam penerapanya membutuhkan people atau orang yang berkompeten sebagai sumber pengetahuan, tempat untuk melakukan sharing knowledge atau diskusi dan isi dari diskusi itu sendiri. Dari ketiga komponen tersebut maka peran teknologi informasi dalam knowledge management adalah mampu menghilangkan kendala mengenai tempat untuk melakukan diskusi, sehingga memungkinkan terjadinya sharing knowledge atau diskusi tanpa harus bertemu secara fisik.16 Dengan demikian pengetahuan atau hasil sharing knowledge dapat diperoleh tanpa harus bertatap muka.

Knowledge management dalam penerapanya didukung oleh sumber daya manusia dan juga teknologi informasi, karena dengan teknologi informasi akan memudahkannya dalam pengaksesan dan peningkatan kualitas dari sharing dan manage knowledge sehingga dapat bermuara pada peningkatan mutu dan daya saing suatu organisasi.

Toumi dan Nonaka sebagaimana yang dikutip oleh Pawit M. Yusuf, berpandangan bahwa pengetahuan yang selalu diciptakan oleh individu-

12Paul L Tobing, Knowledge Management: Konsep, Arsitektur, dan Implementasi, (Yogyakarta: Graha Ilmu, 2007), hlm. 24.

13 Ambar Teguh Sulistiyani, Manajemen Sumber Daya Manusia, (Yogyakarya: Graha Ilmu, 2009), hlm. 11.

14 M.R. Khairul Muluk, Knowledge Management: Kunci Sukses Inovasi Pemerintah Daerah, (Malang: Bayumedia Publishing, 2008), hlm. 22.

15 Rhoni Rodin, "Penerapan Knowledge Management di Perpustakaan: Studi Kasus di Perpustakaan IAIN Curup”, Jurnal Khizanah Alhikmah, Vol. 1. No. 1. 37.

16 Ibid., 
individu dapat dimunculkan dan diperluas oleh organisasi melalui interaksi sosial, baik dalam lingkungan organisasi itu sendiri maupun dari luar organisasi.17 Dengan kata lain bahwa pengetahuan itu berasal dari diri individu-individu organisasi dan dapat dapat diperluas untuk pengitergrasian pemahaman dan informasi dalam rangka peningkatan mutu dan dan saing organisasi atau lembaga pendidikan.

Knowledge dalam management dapat dibagi kedalam dua jenis: Pertama, tacit knowledge ialah merupakan pengetahuan yang masih tersembunyi, masih dibatinkan oleh orang, masih dalam bentuk ide, pemikiran dan sifatnya masih personal. Kedua, explicit knowledge adalah pengetahuan yang sudah dalam bentuk terdokumentasikan, sudah direkam dalam berbagai bentuk alat perekaman, bisa ditransmisikan, bisa dibagi, diperbanyak, dan dihitung secara tertentu jika sudah diwadahi dalam kemasan-kemasan tertentu. Sebagai contoh: buku, makalah, majalah, rekamanan digital, rekamanan audio, rekaman di memory card, flash disk, hard disk dan lain-lain.18

Nonaka sebagaimana yang dikutip Bambang Setiarso menyatakan bahwa proses pencipataan pengetahuan organisasi terjadi karena adanya interaksi (konversi) antara tacit knowledge dan expelicit knowledge melalui proses sosialisasi, ekternalisasi, kombinasi dan internalisasi (SECI).19 Berikut keempat jenis konversi yang disebut sebagai SECI process:

Pertama, sosialisasi ialah merupakan proses sharing dan penciptaan tacit knowledge melalui interaksi dan pengalaman langsung.20 Contoh: rapat, diskusi, pertemuan bulanan dan pengaksesan pengetahuan dari sumber eksternal.21 Kedua, eksternalisasi merupakan pengartikulasian tacit knowledge menjadi explicit knowledge melalui proses dialog dan refleksi.22 Contoh: pengkodifikasian dari hasil sosialisasi.23 Ketiga, kombinasi merupakan proses konversi explicit knowledge menjadi explicit knowledge yang baru melalui sistemisasi dan pengaplikasian explicit knowledge dan informasi.24 Keempat, internalisasi merupakan proses pembelajaran dan akusisi knowledge yang dilakukan oleh anggota organisasi terhadap explicit

17 Pawit M. Yusuf, Prespektif Manajemen Pengetahuan Informasi, Komunikasi, Pendidikan, dan Perpustakaan, (Jakarta: PT RajaGrafindo Persada, 2012), hlm. 47.

18 Ibid, hlm. 6.

19 Bambang Setiarso, et.al., Penerapan Knowledge Management, ..., hlm. 35.

20 Paul L Tobing, Knowledge Management: Konsep, ..., hlm. 21-22.

21 Syahrizal Abba, Manajemen Perguruan Tinggi, (Jakarta: Kencana, 2008), hlm. 130.

22 Paul L Tobing, Knowledge Management: Konsep, ..., hlm. 21-22.

23 Laelatul Badriyah, Manajemen Pengetahuan Dosen dalam Pembelajaran Bahasa Arab di Jurusan Jurusan Pendidikan Bahasa Arab Fakultas Ilmu Tarbiyah dan Keguruan UIN Sunan Kalijaga, (Yogyakarta: Skripsi FITK UIN Sunan Kalijaga), hlm. 15. 24 Paul L Tobing, Knowledge Management: Konsep, ..., hlm. 21-22. 
knowledge yang disebarkan ke seluruh organisasi melalui pengalaman sendiri sehingga menjadi tacit knowledge anggota organisasi.25

SECI process dalam sebuah lembaga pendidikan biasanya diterapkan dalam bentuk sharing-sharing pengetahuan yang dilakukan oleh orangorang/pendidik dari suatu lembaga pendidikan. Sebagai contoh: sharing pengetahuan server. Dimana didalam sebuah komputer disediakan folderfolder yang berisi seluruh document yang biasanya berkaitan dengan admistrasi, termasuk didalamnya pengetahuan-pengetahuan yang di share. Setiap guru di lembaga pendidikan tersebut diwajibkan untuk memasukkan pengetahuan-pengetahuan baru yang dimilikinya kedalam server sehingga guru-guru lain dapat memperoleh, mengakses kumpulan sharing pengetahuan melalui server tersebut. 26

\section{Strategi Penerapan Knowledge Management}

Knowledge management dalam penerapan nya memiliki beberapa strategi, diantaranya:

1. Macro Environment

Lembaga pendidikan harus dapat melihat faktor-faktor eksternal, seperti globalisasi dan teknologi.

2. Organizational Climate

Lingkungan lembaga pendidikan harus mampu melihat struktur formal, tujuan yang akan dicapai serta budaya dilingkungan lembaga pendidikan itu sendiri.

3. Technical Climate

Infrastruktur lembaga pendidikan sangat mempengaruhi lembaga pendidikan untuk berubah dan melihat kebutuhan pengguna.

4. Technical, informational, personal

Memberikan motivasi kepada bawahan sehingga bawahan atau SDM dalam menjalankan tugasnya mampu berkopetensi dengan lembaga pendidikan lain. 27

\section{Faktor-Faktor Pendukung dalam Penerapan Knowledge Management}

Knowledge Management dalam penerapanya di lembaga pendidikan memiliki beberapa faktor yang mendukung kesuksesaannya, sebagai berikut:

1. Corporate Culture

25 Ibid.,

26 "Penerapan Knowledge Management: Studi Kasus SDIT Al-Hamidiyah Depok" dalam Jurnal Majalah Perpustakaan dan Informasi, Vol. 6, No. 1, 2013: 13-14.

27Ida Mariani Pasaribu, "Implementasi Knowledge Management dan Analisis

SWOT di Perpustakaan Perguruan Tinggi”, Universitas Sari Mutiara Indonesia Medan, hlm. 162-163. 
Lembaga pendidikan harus mampu memberikan atau meningkatkan budaya penyebaran informasi.

2. Structure

Struktur yang digunakan lembaga pendidikan adalah untuk mentransfer pengetahuan kepada pengguna. Lembaga pendidikan harus mampu mendesain sistem yang digunakan sebagai penyalur pengetahuan kepada user.

3. Tools of Knowledge Management

Teknologi adalah suatu alat (tool) yang digunakan dalam pegembangan dan penyaluran informasi di lembaga pendidikan.

4. Leadership Style

Keberhasilan Knowledge Management didukung oleh peranan seorang pemimpin, yang menggalang dan mengarahkan partisipasi anggota organisasi dalam mewujudkan visinya.

5. People

Berupa tacit knowledge atau pun explicit knowledge yang dapat di sharing dalam organisasi atau pun sebuah lembaga pendidikan.

6. Innovative Capabilities

Kemampuan belajar dan berinovasi bagi setiap individu sehingga akan muncul ide-ide, inovasi dan pengetahuan baru yang nantinya dapat menjadi komoditas utama dalam knowledge management.

7. Strategy of Knowledge Management

Strategi atau terobosan baru lembaga pendidikan dalam menciptakan pengetahuan baru, sehingga denganya lembaga pendidikan tersebut dapat tetap eksis dalam menjalankan fungsinya. 28

\section{Manfaat Knowledge Management}

Meningkatnya kebutuhan akan manajemen pengetahuan di era saat ini menyediakan berbagai manfaat bagi para penggunanya, manfaat tersebut ialah sebagai berikut: Pertama, manfaat bagi individu, yaitu: manajemen pengetahuan dapat membantu individu memperbaharui informasi atau pengetahuan baru di sebuah organisasi. Kedua, bagi organisasi, yaitu: manajemen pengetahuan dapat mendorong strategi-strategi organisasi. Ketiga, bagi komunitas praktik, yaitu: manajemen pengetahuan dapat menunjang pengawasan antara rekan kerja.29

\section{Tantangan dalam Penerapan Knowledge Management}

Knowledge Management merupakan serangkaian kegiatan mengkoordinasi pengetahuan dalam sebuah organisasi atau lembaga

28 Ibid, hlm. 163-164.

29 Nurul Indarti, en Dhiani Dyahjatmayanti, Manajemen Pengetahuan: Teori ..., hlm. 10. 
pendidikan untuk mencapai tujuanya.30 Knowledge Management dalam penerapanya memiliki beberapa tantangan yaitu dilema sosial, dilema pengetahuan, dan kombinasi keduanya.31

Dikutip dari Verni Juita bahwa hambatan atau tantangan dalam penerapan knowledge management, ialah sebagai berikut: Pertama, kurangnya permodalan dan sumber daya manusia yang berkualitas. Kedua, faktor budaya dan individu. Hal ini dikarenakan budaya mempengaruhi sikap dan tingkah laku pengendalian terhadap tahapan pembuatan dan pengumpulan pengetahuan, pendistribusian dan penggunaan pengetahuan. Ketiga, faktor teknologi dan struktur organisasi yang tepat. Hal ini dikarenakan keberhasilan penerapan program-program knowledge management bisa terjadi jika terdapat kombinasi yang seimbang antara faktor-faktor penting seperti, dukungan manajemen, teknologi dan organisasi yang tepat. 32

\section{Penerapan Knowledge Management di SMK Diponegoro Depok}

1. Biografi SMK Diponegoro Depok

SMK Dipengoro Depok adalah sebuah lembaga pendidikan menengah kejuruan yang ada di Depok Sleman Yogyakarta. SMK Dipenogoro merupakan sekolah menengah kejuruan yang berbasis pesantren, hal ini dikarenakan SMK Diponegoro berada dibawah naungan Yayasan Pondok Pesantren Pangeran Diponegoro sebagai pentransferan ilmu-ilmu agama. Selain itu SMK Diponegoro merupakan satu-satunya SMK binaan dari Fakultas Tekhnik Universitas Yogyakarta.

SMK Diponegoro didirikan pada 23 September 2003. SMK ini terletak di kompleks Pondok Pesantren Pangeran Diponegoro Sembego RT 01 RW 38, Maguwoharjo Depok Sleman Yogyakarta Telp. (0274) 4332220, Kode Pos 56282, Email: Smkdiponegorodepok@gmail.com. SMK Diponegoro memiliki visi menjadi sekolah kejuruan utama yang unggul, terampil, agamis, mandiri dan berakhlak mulia. Saat ini SMK Diponegoro memiliki dua program kejuruan yaitu: kejuruan tekhnik bisnis sepeda motor dan tata busana. SMK Diponegoro saat ini dipimpin oleh bapak Asngari, S.Pd.I selaku kepala sekolah dari SMK Diponegoro.33

30 Thoriq Tri Prabowo, Hubungan Antara Impelementasi Manajemen Pengetahuan dan Kompetisi Pustakawan di Perpustakaan UIN Sunan Kalijaga, (Yogyakarta: Tesis FITK UIN Sunan Kalijaga, 2016), hlm. 31.

31 Paul L Tobing, Knowledge Management: Konsep, ..., hlm. 30-34.

32 Verni Juita, "Faktor Penting Untuk Keberhasilan Penerapan Knowledge Management Pada Pengelolaan Keuangan di UMKM Kota Padang", National Conference of Applied Sciences, Engineering, Business and Information Technology, IISN: 2541-111x, 380. 10.54 WIB.

33 Hasil observasi di SMK Diponegoro Depok pada tasnggal 05 April 2018 pukul 
SMK Diponegoro dimasyarkat dikenal sebagai SMK yang berbasis pesantren yang lulusanya merupakan ahli tekhnik sepeda motor dan tata busana yang bisa mengaji dan hapal juz 30.34

2. Analisis Penerapan Knowledge management di SMK Diponegoro Depok.

Knowledge management berangkat dari konsep pengelolaan dan permberdayaan terhadap sumber daya dan teknologi informasi yang dimiliki. knowledge management dapat dilihat dari dua teori yaitu: teori berbasis sumber daya (resource based theory) dan teori berbasis pengetahuan (knowledge based theory.

Teori berbasis sumber daya adalah teori yang memanfaatkan semua sumber daya dengan sebaik mungkin sehingga dapat meningkatkan efisiensi dan efektifitas lembaga pendidikan. Sedangkan teori berbasis pengetahuan ialah teori yang memandang pengetahuan sebagai sumber daya organisasi yang sangat signifikan.

SMK Diponegoro Depok dalam pemanfaatan sumber daya dan teknhnologi informasi sebagai knowledge management telah memanfaatkanya dengan cukup baik, meskipun didalamnya masih terdapat banyak keterbatasan, penulis ambil contoh kurang signifikanya penerapan website dan instagram sebagai media sharing knowledge. Bentuk pengelolaan dan pemanfaatan sumber daya yang ada di SMK Diponegoro baik itu sumber daya manusia atau pun sarana prasarana yang ada telah berjalan dengan cukup baik, hal ini dapat dilihat dari hasil wawancara dengan kepala sekolah SMK Diponegoro Depok yang mengatakan bahwa telah dilakukanya peningkatan mutu atau kualitas sumber daya manusia yakni dengan diadakanya seminar-seminar, pelatihan teaching factory, dan mengirimkan pendidik dan tenaga kependidikan untuk mengikuti diklatdiklat.35

Terkait dengan pemanfaatan dan peningkatan kualitas sumber daya alam pihak sekolah memanfaatkan bantuan dari pemerintah untuk peningkatan kualitas dari prasarana yang ada, kepala sekolah mengatakan bahwa baru-baru ini SMK Diponegoro Depok mendapat bantuan dari pemerintah kaitanya dengan bantuan pesantren yang berupa alat dan ruang kelas.36 Hal senada juga dikatakan oleh salah satu guru SMK Diponegoro

34 Hasil wawancara dengan bapak Asngari kepala sekolah SMK Diponegoro Depok pada tanggal 26 April 2018 pukul 09.04 WIB.

35 Hasil wawancara dengan bapak Asngari kepala sekolah SMK Diponegoro Depok pada tanggal 11 April 2018 pukul 08.22 WIB.

36 Hasil wawancara dengan bapak Asngari kepala sekolah SMK Diponegoro Depok pada tanggal 11 April 2018 pukul 08.23 WIB. 
Depok bahwa dalam satu tahun minimal pihak sekolahan mengadakan seminar sebanyak dua kali.37

Knowledge management berkaitan langsung dengan sharing knowledge. SMK Diponegoro kaitanya dengan penerapan sharing knowledge memiliki beberapa media informasi yang digunakan untuk promosi, publikasi dan sharing knowledge. Berdasarkan hasil wawancara dengan kepala sekolah SMK Diponegoro Depok, diketahui adanya media sharing sebagai berikut: Pertama, website: www.smkdiponegorojogja.com. Kedua, facebook: SMK Diponegoro Depok Yogyakarta. Ketiga, instagram: @smk_dipo. Keempat, whatapps: group fungsionari, group guru dan tenaga kependidikan smk diponegoro. Kelima, mading. Keenam, perpustakaan.

SMK Diponegoro Depok kaitanya dengan sharing knowledge memanfaatkan teknologi komunikasi dan informasi sebagai medianya, kepala sekolah mengatakan bahwa SMK Diponegoro memiliki website, facebook, dan instagram yang isinya berupa publikasi dan komunikasi mengenai kegiatan yang dilakukan sekolah, kepala sekolah mengatakan bahwa pengelolaan website SMK Diponegoro Depok kurang produktif dikarenakan terbatasnya admin yang mempunyai keahlian dibidang tersebut.38 Hal senada juga disampaikan oleh admin website yang mengatakan bahwa website yang dimiliki sekolah digunakan untuk promosi dan publikasi. Contoh: publikasi terkait pelaksanaan UKKP tata busana.39

Selain media-media diatas SMK Diponegoro juga memanfaatkan whatapps, mading, dan perpustakaan sebagai media sharing knowledge, kepala sekolah mengatakan bahwa adanya group-group whatapps yang digunakan untuk sharing info jadwal ujian, info jadwal pelajaran, sharing permasalahan, dan sharing info-info yang berkaitan dengan kedinasan.40 Berkaitan dengan mading dan perpustakaan, adanya tulisan-tulisan peserta didik yang di share melalui media mading. Kemudian untuk perpustakaan yang ada di SMK Diponegoro menggunakan akses online dan offline, akses online digunakan untuk mencari buku yang tidak ada diperpustakaan melalui dunia maya.41 Sependapat dengan hal diatas ibu Dwi Andriani mengatakan belum adanya perpustakaan digital yang digunakan. Jika bahan pelajaran

37 Hasil wawancara dengan bapak Zulkifli guru di SMK Diponegoro Depok pada tanggal 11 April 2018 pukul 10.05 WIB.

38 Hasil wawancara dengan bapak Asngari kepala sekolah SMK Diponegoro Depok pada tanggal 11 April 2018 pukul 08.11 WIB.

39 Hasil wawancara dengan bapak Suwarno guru dan admin website di SMK Diponegoro Depok pada tanggal 13 April 2018 pukul 09.06 WIB.

40 Hasil wawancara dengan bapak Asngari kepala sekolah SMK Diponegoro Depok pada tanggal 11 April 2018 pukul 08.12 WIB.

41 Hasil wawancara dengan bapak Asngari kepala sekolah SMK Diponegoro Depok pada tanggal 11 April 2018 pukul 08.14 WIB. 
yang dicari tidak ditemukan diperpustakaan maka dapat dicari melalui media internet.42

Penerapan sharing knowledge kaitannya dengan program, pendidik dan peserta didik dapat dilihat dari pembinaan bulanan, pembinaan harian, dan peningkatan pengetahuan guru. Dari hasil wawancara yang dilakukan, kepala sekolah mengatakan adanya pembinaan bulanan atau rapat bulanan terkait penanganan anak, kegiatan belajar mengajar dan lain-lain. Kemudian terkait pembinaan harian dilakukan tiap pagi hari yaitu lima menit sebelum pukul tujuh pagi, dimana semua guru dan tenaga kependidikan harus berada didalam ruangan untuk membaca do'a dan sholawat bersama. Kemudian untuk peningkatan pengetahuan guru diwajibkanya setiap guru dan karyawan untuk bisa mengaji dan belajar ditempat pak kiyai pimpinan Pondok Pesantren Pangeran Diponegoro yang dijadwalkan seminggu sekali setelah sholat dhuha. Hal ini dilakukan untuk mengimbangi program sekolah dan pondok pesantren yang mewajibkan tiap lulusan SMK Diponegoro Depok harus bisa mengaji dan minimal hapal juz 30 sebagai syarat lulusnya.43

Dari beberapa penjelasan diatas maka penulis dapat menganalisis mengenai penerapan knowledge management di SMK Diponegoro Depok, penulis menganalisis berdasarkan hasil observasi, dokumentasi, dan wawancara yang ditemukan dilapangan. Berikut hasil analisis penulis:

Pertama, telah dilakukanya peningkatan dan pemanfaatan sumber daya yang ada. Hal ini dapat dilihat dari adanya pengiriman guru-guru untuk mengikuti diklat, pelatihan teaching factory, seminar-seminar, kegiatan mengaji mingguan, dan pemanfaatan media tekhnologi informasi.

Kedua, adanya penerapan sharing knowledge. Hal ini dapat dilihat dari adanya pembinaan harian, yaitu lima menit sebelum masuk jam pelajaran semua guru berkumpul diruang guru membaca do'a, membaca sholawat. Pembinaan bulanan, yaitu rapat bulanan yang membahas permasalahan yang terjadi di kelas. Pembinaan terhadap guru yang indisipliner yaitu dengan bicara empat mata dari hati kehati. Peningkatan kualitas guru, yaitu mengirim guru untuk mengikuti diklat, seminar-seminar, dan mengaji di tempat pak kiyai. Penggunaan media tekhnologi dan informasi yaitu berupa website, facebook, instagram, whatapps, mading, dan perpustakaan.

Ketiga, SMK Diponegoro melakukan sebuah terbosan dalam peningkatan kualitas pengetahuan peserta didik dan guru yaitu dengan diwajibkanya para guru dan peserta didik untuk bisa mengaji, dan syarat lulus bagi peserta didik yang telah bisa mengaji adalah hapal jus 30 .

42 Hasil wawancara dengan ibu Dwi Andriani guru dan pustakawan di SMK Diponegoro Depok pada tanggal 11 April 2018 pukul 09.13 WIB.

43Hasil wawancara dengan bapak Asngari, SPd.I kepala sekolah SMK Diponegoro Depok pada tanggal 11 April 2018 pukul 08.43 WIB. 
Keempat, SMK Diponegoro telah mampu melihat peluang besar dari budaya penyebaran informasi terhadap peningkatan kualitas dan daya saing dari lembaga pendidikan tersebut. Hal ini terlihat dari adanya publikasi dan promosi mengenai kegiatatan-kegiatan yang dilakukan yang di share melalui website, facebook, atau pun instagram.

Kelima, kurang signifikanya penggunaan media tekhnologi komunikasi dan informasi yaitu website, facebook, dan instagram yang kebanyakan digunakan untuk publikasi kegiatan dan promosi-promosi sekolah.

\section{PENUTUP}

Knowledge Management merupakan konsep pengelolaan dan pemanfaatan sumber daya dan teknologi informasi yang dimiliki sebagai suatu aset pengetahuan dalam meningkatkan keunggulan yang kompetitif. Knowledge Management berangkat dari dua teori yaitu teori berbasis sumber daya dan teori berbasis pengetahuan. Teori berbasis sumber daya memandang bahwa semua sumber daya dapat digunakan sebaik mungkin sehingga dapat meningkatkan kualitas dari suatu perusahaan atau lemabaga pendidikan. Sedangkan teori berbasis pengatahuan sebagai sumberdaya organisasi yang paling siginifikan. Berdasarkan analisis penulis terkait teori dan penerapan Knowledge Management di SMK Diponegoro Depok maka penulis menemukan hal-hal, sebagai berikut: (1) Telah dilakukanya peningkatan dan pemanfaatan sumber daya (2) Adanya penerapan sharing knowledge (3) Dilakukanya terbosan dalam peningkatan kualitas pendidik dan peserta didik (4) SMK Diponegoro mampu melihat peluang besar dari budaya penyebaran informasi (5) Kurang signifikanya penggunaan media tekhnologi komunikasi dan informasi di SMK Diponegoro Depok.

\section{DAFTAR PUSTAKA}

Abba, Syahrizal. Manajemen Perguruan Tinggi. Jakarta: Kencana. 2008.

Abdul Amin. "Knowledge Management: Konsep dan Aplikasinya di Perpustakaan". Jurnal Al-Maktabah. Vol. 2. No. 2.

Badriyah, Laelatul. Manajemen Pengetahuan Dosen dalam Pembelajaran Bahasa Arab di Jurusan Jurusan Pendidikan Bahasa Arab Fakultas Ilmu Tarbiyah dan Keguruan UIN Sunan Kalijaga. Yogyakarta: Skripsi FITK UIN $\quad$ Sunan Kalijaga. 2014.

Ferdinandus, Elsina et.al. "Model Knowledge Management dalam Organisasi Pendidikan". Jurnal Pendidikan Humaniora. Vol. 3. No. 2.

Indarti, Nurul en Dyahjatmayanti, Dhiani. Manajemen Pengetahuan: Teori dan Praktik. Yogyakarta: Gadjah Mada University Press. 2015. 
Juita, Verni. "Faktor Penting Untuk Keberhasilan Penerapan Knowledge Management Pada Pengelolaan Keuangan di UMKM Kota Padang”. $\quad$ National Conference of Applied Sciences, Engineering, Business and Information Technology. IISN: 2541-111x. 2016.

Muluk M.R. Khairul. Knowledge Management: Kunci Sukses Inovasi Pemerintah Daerah. Malang: Bayumedia Publishing. 2008.

Pasaribu, Ida Mariani. "Implementasi Knowledge Management dan Analisis SWOT di Perpustakaan Perguruan Tinggi”. Universitas Sari Mutiara Indonesia Medan.

Penerapan Knowledge Management: Studi Kasus SDIT Al-Hamidiyah Depok. Jurnal Majalah Perpustakaan dan Informasi. Vol. 6. No. 1. 2013.

Prabowo, Thoriq Tri. Hubungan Antara Impelementasi Manajemen Pengetahuan dan Kompetisi Pustakawan di Perpustakaan UIN Sunan Kalijaga. Yogyakarta: Tesis FITK UIN Sunan Kalijaga. 2016.

Rodin, Rhoni. "Penerapan Knowledge Management di Perpustakaan: Studi Kasus di Perpustakaan IAIN Curup". Jurnal Khizanah Alhikmah. Vol. 1. No. 1.

Sangkala. Knowledge Management. Jakarta: PT Grafindo Persada. 2007.

Setiarso, Bambang et. al. Penerapan Knowledge Management Pada

Organisasi. Yogyakarta: Graha Ilmu. 2012.

Sopandi, Omar Dani. "Implementasi Knowledge Management Pada

Perguruan Tinggi”. Jurnal Admistrasi Pendidikan, Vol. XXII. No.2.

Sulistiyani, Ambar Teguh. Manajemen Sumber Daya Manusia. Yogyakarya: Graha Ilmu. 2009.

Tobing, Paul L. Knowledge Management: Konsep, Arsitektur, dan Implementasi. Yogyakarta: Graha Ilmu. 2007.

Yusuf, Pawit M. Prespektif Manajemen Pengetahuan Informasi, Komunikasi, Pendidikan, dan Perpustakaan. Jakarta: PT Raja Grafindo Persada. 2012. 